\title{
Between Market, State and Society: Labour Codes of Conduct in the Southern African Garment Industry
}

\author{
Andries Bezuidenhout \\ Associate Professor \\ Department of Sociology, University of Pretoria \\ Pretoria, 0001 \\ $+27124204908$ \\ andries.bezuidenhout@up.ac.za
}

\begin{abstract}
Søren Jeppesen
Associate Professor

Centre for Business and Development Studies, Copenhagen Business School

Porcelænshaven 18A

DK-2000 Frederiksberg

$+4538153363$

sj.ikl@,cbs.dk
\end{abstract}

Corresponding author: andries.bezuidenhout@up.ac.za 


\section{Abstract}

This paper compares how workers experience the interaction between mechanisms to inspect labour codes of conduct with government functions and trade unions in garment factories in South Africa, Swaziland and Lesotho. In South Africa and Swaziland there was little awareness of the potential impact such instruments on working conditions. In Lesotho, where there is a high profile campaign, workers are more aware of such codes, but confusion over who visitors to factories are and corporate whitewash limit the impact of instruments. In all three countries workers perceived the impact of codes of conduct on labour rights as negligible. This differed between firms, with workers in firms supplying to the higher end of the South African market being more positive. Given the absence of coherent global governance of trade in the garment industry, codes of conduct will remain an inadequate response to the abuse of workers' rights, also in southern Africa.

\section{Codes of Conduct and Labour Repressive Regimes}

In her book Beyond the Boycott (2007), Gay Seidman argues that labour codes of conduct (hereafter 'codes'), i.e. voluntary guidelines defining 'the ethical behaviour that a company intends to practice during its operations and through its supply chain' (Jenkins, et al., 2002: 1), tend to detract from attempts to enhance state capacity to enforce labour standards. This is because transnational activists often frame labour rights transgressions as human rights abuses in order to attract the attention of global audiences, diverting attention from less spectacular, run of the mill violations of labour rights by corporations; often the interests of local labour activists in the global South are ignored or underplayed by transnational activists, who coordinate consumer boycotts in the North; and so-called independent agencies tasked with monitoring these codes become dependent on contracts from their clients, thus compromising their independence. Rather than creating 'privatised regulatory schemes', Seidman argues, 'transnational campaigns should shift their efforts to strengthening the institutions of democratic citizenship.' When such campaigns strengthen the voices of workers themselves, rather than 'simply publicizing the worst kinds of abuses', they may achieve this more readily (Seidman, 2007: 144; also see Seidman, 2008). 
Seidman's critique of codes should be read against the backdrop of companies moving production to labour repressive regimes (Silver, 2003; Bonachich \& Appelbaum, 2000). Codes of conduct, driven by Northern consumer movements, have been presented as an alternative to state regulation, or the lack thereof. Seidman's is one of a number of critiques of this new framework.

These are valid criticisms, but a problem remains. It does not address the dilemma that such states are often unwilling, and sometimes even incapable of protecting minimum labour standards. According to Michael Burawoy (2010), Seidman fails to 'examine the relation of state and society to understand when the state might protect the interests of labour or when it might mount an assault on labour.' He elaborates: '[Seidman] follows the Nirvana Principle, according to which rejecting one solution, ipso facto makes its alternative preferable. Just because international solidarity is both infeasible and problematic does not of itself imply that focusing on the state provides any better solution. In the contemporary era states have been notoriously hostile to labour' (Burawoy, 2010: 303-4).

Indeed, codes of conduct often arise when states follow labour repressive policies (Jenkins, et al., 2002; Barrientos \& Smith, 2007; Locke \& Romis, 2009). In the South African case, whilst quite critical of voluntary initiatives such as the Sullivan Principles, trade unions in the seventies and eighties strategically used it to put pressure on multinational corporations to recognise trade unions for black workers (see Southall, 1995; Fig, 2007). Our aim here is to explore the interaction between states, companies, workers, trade unions and international campaigns around codes comparatively. We are interested in the relationships and possibilities created on the ground by the interaction between codes of conduct inspectors, government officials, and trade union activists. Could these global connections strengthen local social institutions in any way, or do they necessarily undermine the state and civil society? 
Instead of choosing three similar cases of labour repression, we examine the garment manufacturing industries of three southern African countries - South Africa, Lesotho and Swaziland - because they illustrate different dynamics. South Africa is ostensibly a country with good labour laws, and it is thus assumed that workers do not require the additional protection of private sector regulation. Lesotho is a country where codes, particularly one introduced by the Los Angeles based company The GAP, have come to play a very prominent role (see Seidman, 2009). Swaziland, Africa's last remaining absolute monarchy, is a labour repressive regime and, curiously enough, much less international attention is paid to labour abuses here than in Lesotho.

We use a number of methods, including direct observation, interviews (semi-structured and open) and the analysis of documents. Data was gathered during four fieldtrips in South Africa, Swaziland and Lesotho in 2008 and 2011. Due to the size difference between the countries, we focused in South Africa on the town of Ladysmith in KwaZulu-Natal. It is a traditional garment producing area, which like the rest of the South African garment industry has experienced considerable changes over the last 15-20 years. We conducted interviews with 11 managers and 121 workers from 12 factories; 5 in Swaziland, 4 in Lesotho and 3 in South Africa (see Appendix A). In Swaziland interviews with workers were conducted by Penuel Malinga and Xolile Dlamini, in Lesotho by Lineo Ramabele, and in South Africa by Lindiwe Hlatswayo. All interviews were conducted in the home languages of workers. Since the selection of employees for interviews by codes of conduct inspectors is such a sensitive matter, interviews with workers took place outside factory gates or in the home environment of the workers, in order to avoid interference from the managers, making random sampling impossible.

These interviews yielded quantitative and qualitative data. Where we draw on quantitative data to compare working conditions in the three countries, we by no means suggest that the 
findings can be generalised. We do not use inferential statistics and our data should be treated as descriptions of the working conditions of only those workers we interviewed, applicable only (but not generalised to) to the factories where they work. We use qualitative data to supplement and exemplify the quantitative findings. We furthermore interviewed 34 key informants among government agencies, consultants, trade associations (employers and unions), in the countries, based on an open interview schedule (see Appendix B).

We first provide background information on the garment manufacturing industries of the three countries. Mainly based on the interviews with workers, we then look at how codes play out in practice, focusing on (i) workers' knowledge of how codes operate, (ii) regulation by the state, (iii) and the role of trade unions in garment factories.

\section{The Garment Industry in Southern Africa}

Because of its ability to shift production easily, the garment industry is often referred to as a 'footloose industry' (Gibbon, 2002; Ravioli, 2006; Seidman, 2009). However, it is also considered to be a 'foot in the door industry', a key industry in kick-starting industrial development (Gereffi, 1995; DfID, 2000), meaning that developing countries often attempt to attract foreign investors from the industry.

With industrialised countries holding the main buying power in the industry, so-called buyerdriven global value chains structure the intensive competition in the industry with one outcome being a predominant emphasis on cost control and efficiency (Gereffi \& Memedovic, 2003; Kaplinsky, 2005). Fierce competition among governments to provide incentives has resulted in low wages and poor working conditions, described by some as a race to bottom (Silver, 2003). 
In the 1980s and 1990s the industry's geography and Africa's share in production were influenced by global regulation through the Multi-Fibre Agreement (MFA). From 1994-2004 these were affected by the Agreement on Textiles and Clothing (ATC), where a quota system ensured a spread of global production. The MFA/ATC and the African Growth and Opportunity Act (AGOA), promulgated by the USA in May 2000, led to the sourcing of garments from a number of African countries. Nevertheless, Africa remains a minor player, with sub-Saharan Africa constituting a mere $2.6 \%$ of global textiles export, and $3.7 \%$ of clothing exports (Kaplinsky \& Morris, 2008: 260).

In the early 2000s South Africa, Lesotho and Swaziland also saw an influx of clothing manufacturers. A contributing factor was that the South African currency, the 'rand' (R), to which Lesotho and Swaziland's currencies are tied, was favourable to the US dollar at the time. In Lesotho 50000 new jobs were created, and in Swaziland 40 000. Mostly young women work in these factories, producing merchandise such as jeans and T-shirts for the US market. These are massive orders with low margins, but high profits because of the size of the orders (Bennett, 2006; Madonsela, 2006). AGOA's impact is more difficult to establish in South Africa. Some companies benefitted, but numerous firms closed simultaneously due to the ending of the ATC. Most firms focused on domestic markets and were under pressure from imports (Vlok, 2006; Jeppesen \& Barnes, 2011).

The pressure resulting from the ending of the ATC was magnified when, around 2005, the Rand nearly doubled in value to the dollar from its levels in early 2000 , which came as a shock to exporters. Lesotho and Swaziland lost 20-30 000 jobs each as manufactures relocated to e.g. China and Vietnam. By December 2010, the industry employed just over 38000 workers in Lesotho (Interview: Mohapi), and at the beginning of 2011, an estimated 18000 employees in Swaziland (Interview: Nkambule). In South Africa, the decline of the industry accelerated. In March 1996, the industry employed approximately 228000 workers. 
In 2003 the figure was around 143 000. The downward trend continued after 2003 and by end 2010 only about 80000 persons were employed (see Morris \& Reed, 2008; Bennett, 2006; Madonsela, 2006; Vlok, 2006: 230; Jeppesen \& Barnes, 2011). Empty factory space in Lesotho and Swaziland was often filled by relocated South African operations.

This is the context in which campaigns to implement code operate. Lesotho is classified as a 'least developed country', with the clothing industry representing the first major industrialisation within the country. Lesotho has aggressively been targeted by international activists because of sweatshop conditions, leading to high profile campaigns around codes (Seidman, 2009). This led to the GAP, one of the major US companies that sources products from this country, implementing codes in factories that supply garments for the US market. There are two full-time inspectors tasked with enforcing the GAP's codes in Lesotho. The International Labour Organisation (ILO) has also paid particular attention to the case of Lesotho, and introduced a Better Work Programme from 2010 onwards, in association with the International Finance Corporation (Interview: Kurths). Swaziland, on the other hand, has received much less attention for such activism (apart from a study by the Centre for Research on Multinational Corporations), though it was almost excluded from the AGOA due to its labour repressive stance (De Haan \& Stichele, 2007). Curiously enough, no major campaigns have emerged to force firms to abide by such codes in Swaziland. Finally, South Africa has received almost no attention. This is perhaps less puzzling than Swaziland, since South Africa's labour regime is often presented as one of the most progressive in the world (Barrientos, et al., 2003). Seemingly, campaigning for codes in this context might appear misguided. This is based on the assumption that national labour laws are actually implemented in factories. Our research findings seem to problematise this assumption. 


\section{Performing Inspections: Workers' Engagement with Codes of Conduct}

How do workers experience codes in their workplaces? What are the differences between the three countries, and between companies operating there? At the very basic level, workers in Lesotho tended to be more aware of whether codes were applicable to their workplaces, where $65 \%$ of those we interviewed said that codes applied to them. In Swaziland, the proportion was 58\% and in South Africa 47\%. More workers in Swaziland and South Africa were uncertain than in Lesotho (see Table 1).

\section{TABLE 1 ABOUT HERE}

In addition to these general differences between the countries, there were great variations between firms within the three countries. At factories that supplied garments for the higher end of the South African market, codes were in place. However, workers were generally confused about whether people who visited the factory were codes of conduct inspectors, or just inspecting garments on behalf of buyers. A 26 year old packer mentioned: 'I've seen people who check the work, but I'm not sure if it is these inspectors.' She felt this made workers 'more efficient.' A 35 year old packer said: 'I've seen people come in, but I think they are from companies we sew for, because they check for rejects and whether we have packed properly.' At another factory, a 31 year old machinist, said. 'They go through all the departments checking work, quality of work, the machines... They have reduced wastage and our machines are in a good condition, and this prevents needle accidents,' she said. Our interviews with managers in these firms confirmed that individual company codes merely 
required them to abide by labour and health and safety laws, and inspections were of a general nature.

The picture was completely different at the other South African factories. At one, we were unable to gain access in spite of an appointment with management. The company gates were locked and our local fieldworker could only interview a single worker. Another firm, where we were at least able to interview workers, paid the lowest average wage to its employees of all the factories included in the study (for more detail, see Table 5). This was well below the minimum set by the bargaining council agreement between employers and the union (Interview: Mhlongo). The firm mostly supplied to the lower end of the South African market. Here, very few interviewees were aware of inspectors who enforced codes. A 22 year old runner said: 'I've seen inspectors, but I'm not sure if they come for the code... They check around the company looking at the work, the machines and talk to some people.' There were however regular inspections by buyers who were concerned about the quality of garments.

As in the case of South Africa, there were major differences between factories in Swaziland. One factory was regularly visited by codes inspectors. A machinist explained: 'They go around the factory and inspect us while we are working. They then pick some of us for interviews about our working conditions.' Another mentioned that workers were selected at random for interviews. A 33 year old trimmer felt that codes had improved the cleanliness of the factory, and led to the introduction of different toilets for men and women. In spite of these positive impacts at this specific firm, there seemed to be some systematic deception when it came to inspections. A 24 year old helper mentioned the fact that 'the company gives us safety masks when the buyers are coming.' This was confirmed by a 26 year old quality controller, who said that 'the management tell us not to tell the truth' to code inspectors. Yet another said: 'We will lose our jobs if they know the truth, as the company will close down.' 
This was also the case at another firm, where workers felt the codes had impacted positively. They saw their on-site clinic, the bread rolls all workers received with tea (intended as nutrition for workers who have to take antiretroviral medication for HIV/Aids), as well as safety material as a direct consequence of the code. But even here workers were told by the company 'not to speak bad about the company as we may lose our orders and it will have an impact on our salaries'. A worker said: 'The HR manager once called us into a meeting and told us not to badmouth the company to the buyers because the company loses when the buyers are told the truth.'

In contrast to these Swaziland firms, where there were at least some attempts to implement codes, others seemed more cynical. A personnel officer at one of them said the procedure was for them to "select workers who are experienced or senior in the factory, as they understand our operations' to be interviewed by codes inspectors. A worker was more frank about the process:

'There are people from other countries [who] come to the factory. They normally select people to be interviewed by the inspectors. They normally call a meeting for all the workers that would be interviewed. I am one of those. We are told by management not to talk bad about the factory, for example safety clothing and the company doctor.

Before they come, we are all given safety masks to cover our faces, as well as uniforms. If you tell the inspectors what they said [i.e. told you to say], they sometimes give you a day off with pay, or whenever you ask to go to hospital or to attend [to] family problems you are free to go. The supervisor will do you a favour.'

At another factory, a 26 year old woman and a member of the Swaziland Manufacturing and Allied Workers' Union (SMAWU), explained: 
'If you were once interviewed by inspectors and you spent time with them explaining, then you are in trouble. They suspect that you are now telling them the truth about the factory. They will target you. If you make a mistake they will shout and make you sign a warning letter... If you want a good relationship with management, don't use your brain, don't join a union, do not complain about heat, dust, or whatever.'

Thus far we have seen significant differences emerging between firms both South Africa and Swaziland. In Lesotho, the approach was more homogenous, with firms competing for export, mass markets. Here $65 \%$ of the workers we interviewed were aware of codes in their workplaces. However, workers sometimes confused codes with their production scores. Very few were aware of people from outside their firms who inspected working conditions. A 39 year old machinist even remarked: 'People from outside are not allowed in the firm.' About their code of conduct, a 32 year old ironer said: 'Yes, but it is not used.' A 27 year old male packer said: 'There is no change in the firm. We are depending on the Chinese decisions, not other things.' Another, a 24 year old female cutter, said: 'No change, because they [codes] are not exactly applied. It's the final discretion of the Chinese.' At one factory, some workers were under the impression that it referred to the fact that they were not allowed to eat or talk while working. Here, a 30 year old machinist said: 'Yes, but the target is the most important.'

At one factory, a 23 year old machinist related how annual inspections by buyers were carried out: 'When they come all of us have to put on our nose bags and when you don't have it you have to go home that day, otherwise it might be a bad reflection to the visitors.' Sometimes, when the 'buyers' visit, workers are sent home at 10:00.

In summary, while there were basic levels of awareness of codes among the workers we interviewed, there were higher levels of awareness in Lesotho than the other two countries. Differences between firms related to how they fit into production networks, with firms in 
South Africa and Swaziland supplying the higher end of the South African market being subjected to codes. In Lesotho there were fewer differences between firms. When engaging the interviews with workers closely, it is clear that a majority of firms - even those that seem to have better labour practices than other - engage in performances for the benefit of inspectors, and expect workers to go along with these performances. As a result, workers' understandings of inspections are tied up with these performances and they seem to internalise the logic of "putting forward your best foot".

\section{The State and Labour Inspections}

We now turn to an analysis of how workers saw the state and its enforcement functions, a rather dire picture in all three countries (see Table 2 below). Indeed, only $23 \%$ of South Africans, $8 \%$ of Basotho workers, and $12 \%$ of the Swazi workers we interviewed were aware of government officials monitoring their wages and working conditions.

\section{TABLE 2 ABOUT HERE}

At some of the factories in South Africa workers were aware of visits by the Department of Labour, who enquired about their wages and whether they were satisfied with their wage levels. However, in spite of complaints, nothing was done about the situation. There were fewer differences between the factories. A 31 year old machinist said government inspectors visited the factory about two times a year, and ask 'workers about their salaries and working conditions.' She added: 'When they come, the boss disappears.' Another said: 'I can't say. Many people visit the company, but mostly it is people from the stores we are sewing for.' At 
one of the factories none of the workers interviewed had ever seen an inspector from the Department of Labour.

Our interviews with an official from the Department of Labour and a representative from the bargaining council (a centralized negotiation forum for employers and unions in the industry that sets minimum wages) revealed a fragmented and under-resourced inspection system. Employers often refuse inspectors entry, and the police are too understaffed to enforce such functions (Interviews: Mhlongo, Madlala, Wenham \& Steenkamp).

In Swaziland, where trade unions are seen to be part of the opposition to the monarchy, the role of the state is highly controversial. Here labour inspectors had better conditions than colleagues in Lesotho and South Africa. However, in spite of more regular inspections, the influence was limited. A key reason seemed to be that foreign garment companies were seen as 'friends of the king', which implied that workers had to treat them as such. Also, the inspectors had little influence relative to other government departments (Interviews: Nkhambule \& Dlamini). At one of the factories a certain minister was mentioned by name, and his role described as follows:

'He is not monitoring the company if it conforms to the regulations set by government. One thing we are sure of is that the minister is a friend to our company director. They regularly visit his home and donate food and other building material. We don't think the minister would do his job in terms of monitoring the wages and codes of conduct due to his relationship with the company directors.'

Another interviewee said: 'Even the minister once told us that we must respect our company, because if we talk bad about our company to strangers we may anger our bosses and they may close and we lose our jobs.' She expanded: 
'The minister once visited our factory and he addressed the workers. In his address he told us that the money we are getting is far better than what the company is paying in other countries. He did not mention the country he was referring to. As Swazis we grow up respecting our leaders and we are told that they cannot lie to their people. But we feel that government is doing nothing about our wages. We are suffering.'

In Lesotho, as in Swaziland and South Africa, a lack of resources and political will constrained government enforcement. The Department of Labour here competed with other government departments for the use of vehicles, leading to inspections happening rarely (Interview: Matsoso). Not surprisingly, then, very few workers in Lesotho were aware of their wages and working conditions being monitored by the government. They only came 'when there are strikes,' said a 30 year old checker, 'once in a blue moon.' A 25 year old male machinist from another factory said: 'Before I used to see the government vehicle parked outside the firm when I used to queue outside for work, but not any longer.'

Given this absence of state regulation, codes can potentially fill the vacuum. After negative publicity on working conditions in Lesotho, The Gap took initiative and followed through with regular monitoring. This international attention created the space for a government initiative aimed at skills development in the industry (see Commark, 2003, 2007) and a public-private partnership, the ALAFA (Apparel Lesotho Alliance to fight AIDS) initiative, including the government, international donor agencies and local companies, addressing HIV/Aids and ensuring a clinic or regular presence of medical personnel at each participating company (Interview: Chen). As Seidman (2009) points out, Lesotho consequentially attempted to position itself as a "sweat-free" investment destination. More recently the ILO/IFC introduced their Better Work Porgramme in the country. While there is regular contact between the Labour Commissioner and code inspectors, as well as the involvement of 
the Labour Department in the Better Work Programme, none of these initiatives seem to strengthen state capacity to enforce labour rights.

We see in all three countries, in spite of some variation, confusion among workers over whether codes apply to their factories, as well as how the inspection functions are supposed to operate. These misunderstandings are tied up with workers being required to perform inspections in order for companies to retain their contracts with buyers. Added to this is the lack of enforcement of rights and standards by government departments. Given this, what impact do codes have on the ability of workers to enforce their rights through collective organisation? We now turn to an analysis of how the workers we interviewed experienced the role of trade unions.

\section{Trade Unions and Codes of Conduct}

Workers' ability to bargain collectively over wages and conditions would imply the right to freedom of association and the right to free collective bargaining, which form part of all codes. We look at levels of union membership and presence of the unions at the factories as indicators. We were specifically interested in the interplay between codes and unions.

There were major differences regarding the attention workers got from trade unions. The unions in Lesotho tended to visit workplaces much more often than their counterparts in South Africa and Swaziland (see Table 3). However, while about half of the workers in South Africa had never encountered a union representative, the situation in Swaziland was mostly one of unions not being allowed on to factory premises.

\section{TABLE 3 ABOUT HERE}


South Africa had the lowest union membership; with only $23 \%$ of those we interviewed indicating that they were members. There were significant differences between the factories where we interviewed workers (see Table 4).

\section{TABLE 4 ABOUT HERE}

The Southern African Clothing and Allied Workers' Union (SACTWU) was represented in two of the South African firms that complied with labour law and being rated as having good practices (Interview: Mthembu). Nevertheless, younger workers were becoming cynical about unions, as a 20 year old runner said: 'Most people do not use unions and if they are dismissed, they don't report it most of the time. They just want the money due to them and get out.' A worker at another factory explained why she was not a union member: 'Because unions are not effective. There was money deducted from us, but when people go to the bargaining council, existence of these payments is denied.'

Nevertheless, several employees at these factories were union members and mentioned that the union had protected them from being dismissed in the past. One said: 'I just joined, because everybody was doing so and because I might need their help someday.'

Reasons why workers were not union members were different at the low-paying South African operation. Workers mentioned that they did not want to join unions, because they could not afford to pay subscription fees. 'I am already earning too little. I can't afford the union subscription fee,' said a 24 year old employee, who earned around R30 per day. A 29 
year old machinist: 'I don't need it [the union]. I'm not planning to stay at the firms for long, just for experience and then I can go to better paying firms.'

In South Africa, unions are successful in organising workers in formal, registered companies. They seem comfortable in this position, maintaining levels of membership among those who are easily serviced. But due the state's inability to enforce the legislation, informalisation takes place and sweatshop-like entities proliferate, now accounting for more than $90 \%$ of the companies in the Ladysmith/Emnambithi area. Hence, a major segment of the labour market remained unrepresented. To make matters worse, workers in these companies seemed disillusioned with unions and saw little reason for being union members. Because South Africa is seen as a country with good labour laws, there is also little engagement by the labour movement with codes as an organising strategy at the local level. At the national level, unions had attempted, mostly unsuccessfully, to get South African retailers to implement codes in their workplaces. We saw no evidence, however, of these campaigns filtering through to the local level. Indeed, illustrating the extent to which the logic of codes had still not filtered through to South African buyers, Michael Lawrence, the executive director of South Africa's National Clothing Retailers Federation (NCRF), said in September 2010: 'Though we typically don't do work with noncompliant manufacturers, the reality of the supply chain is so complex that work gets passed on (to non-compliant factories)... It is not our job to do the policing' (I-Net Bridge, 2010).

The highest union membership was in Swaziland, where $46 \%$ of those we interviewed were members. There were differences here between companies that supply the higher end of the South African market and those that are linked into lower-end markets, sometimes as subcontractors to other operations. We start with a discussion of the former. At one of these factories, a 32 year old female machinist, also a union member, proudly mentioned: 'The union is our voice when we want to talk to management. They look after our welfare as 
workers.' According to her, the union regularly visited the workplace to report back on their negotiations with management. A 25 year old machinist mentioned that communication between workers and management had been 'difficult in the past, but,' she said, 'last week the director came and told us to report our complaints to the shop-stewards, who will then tell him. With these changes we hope we will have smoother communication.' Another, a 24 year old machinist, told how her contract was terminated unlawfully, but that the union had represented her and she had won her case.

But at other companies in Swaziland there were serious cases of union-bashing. A worker related how the company had built a wall around the premises, 'to ensure that workers during lunch do not talk to union organisers or leaders. Once you are seen talking to union leaders you are automatically fired.' Nevertheless, she joined the union in July 2007, and they 'only meet the union leaders in our rented flats.' This was essentially confirmed by a personnel officer, whose opinion was that their factory was 'one of the best,' since there was no union. He explained: 'We communicate with the workers directly through their workers committee. As a company we realised that unions cause unrest, strikes and a lot of problems in the textile industry.' He confirmed that unions were not allowed access to the premises.

There was a similar situation at another factory, where an interviewee said: 'Our bosses do not want us to be union members. Once they find out that you are a member of a union you are fired.' Union officials were not allowed onto the premises. A 22 year old packer:

'I am scared of dismissal from work once management discovers that I am a member of a union. Some colleagues of mine were dismissed in the past for being members of the union. The management believe[s] that once there are members of a union in the company they will influence the other workers to riot against the management... The union normally come[s] and wait[s] at the gate to recruit us, but no-one goes to them 
for fear of victimisation. During our lunch, the Chinese are at the gate to monitor our movements, even after work.'

A 22 year old woman who works in the cutting department explained what happened during the previous strike:

'With the last strike... we were told not to take part and security was provided by the government to help us go to work. At work there was police. Later, after the strike, the minister came to the factory and he thanked us for not taking part in the strike action. He said it showed that we appreciate[d] our working conditions.'

In Swaziland, the unions were at loggerheads with the king as the factory owners and managers were perceived to be 'friends of the king'. Criticising them was similar to criticising the king. In spite of codes, companies here seemed to succeed in keeping unions out of their firms. Companies that did recognise unions did so because of the nature of their markets and production process, rather than codes. In contrast to Lesotho, unions in Swaziland considered codes as irrelevant to their local struggles. One of the union organisers told us how they had contacted the US retailer Wal-Mart about labour rights abuses. The retailer's response had been to instantaneously cancel the contract with the Swaziland supplier, resulting in most of the workers in the factory losing their jobs (Interviews: Gina \& Simelane; Fakudze \& Manana).

Instead, unions relied on collective bargaining and succeeded in establishing industry-wide bargaining for an industry for the first time in Swaziland's history. Their success was short lived however, because the employers ended the arrangement by collapsing their representative body, the Swaziland Textiles Exporter's Association (STEA) in 2008. By 2011, the most significant union, SMAWU, was weakened by internal squabbles and allegations of corruption (Interview: Nkambule). 
When it comes to Lesotho, Table 3 above presents a bit of a puzzle. The fact that unions in Lesotho visited workplaces regularly, mostly once a week, did not mean that workers necessarily joined unions. Only $25 \%$ of the workers we interviewed were union members. How do we explain this? Again, as in previous sections above, there were no major differences between factories in Lesotho. A 33 year old male sewing machine operator explained why he was not a union member: 'I have been a member in the past, but this time around I decided I will not join. I was a member when I was retrenched, and I paid for nothing.' He also mentioned inter-union rivalry between LECAWU (Lesotho Clothing and Allied Workers Union) and FAWU (Factories and Allied Workers Union) at the factory: 'In this company there are two unions... They always compete for membership and this has created problems within the unions themselves. The type of service they offer is also compromised.' The low membership for Lesotho was consistent with the union strategy of relying on pressure via codes of conduct inspectors to enforce minimum standards, rather than active organisation. Correspondence from the unions to local manufacturers was often 'cc'ed' to the retailers' offices in the US, so as to increase pressure on them to respond to union demands. This was confirmed by interviews with trade unionists, as well as other informants (Interviews: Billy \& Likoti; Maraisane).

Lesotho, then, illustrates how divisions among workers and a lack of union initiative can lead to codes standing in for organising, instead of making it possible. Unions seem to rely on symbolic pressure (by faxing their grievances to buyers) rather than real workers' organisation. It is questionable whether this approach could be construed as codes opening up space for union organisation.

In summary, what does this analysis of the extent to which workers are able to assert their labour rights tell us about codes? Unions were clearly in a difficult position and were only able to make a difference to some extent. In both South Africa and Swaziland there were 
major differences between firms, which relate more to the market segments served by firms than the impact of codes. In both countries, unions did not really engage with codes as tools for organising, in Swaziland because they had burnt their fingers when a major contract was taken away from a producer. Lesotho had the potential for unions to use codes as organising tools, due to the high profile campaigns around US retailers. Nevertheless, the country is a clear example of what happens when codes take the place of real union organising, showing the perverse effects they can have.

\section{Conclusion: A Developmental Dilemma}

Which relationships and possibilities are created on the ground by the interaction between codes of conduct inspectors (market regulation), government officials (state regulation), and trade union activists (social regulation)? Could these connections strengthen local institutions in any way, or do they necessarily undermine the state and civil society? Our findings showed that workers in the three countries had different experiences of codes. In South Africa and Swaziland there was little awareness of the potential impact such instruments could have on working conditions. In Lesotho, where there was a high profile campaign, workers were more aware of such codes, but confusion over who various visitors to factories are and active corporate deception of inspectors diminish the importance of the instruments. Quite understandably, workers perceived the impact of the implementation of codes on labour rights and standards their firms as negligible. This differed between firms, with workers in firms supplying to the higher end of the South African market being more positive. But this could also be related to the better working conditions demanded by the labour process itself, rather than codes as such. Table 5 provides a breakdown of the average wages of workers we interviewed by firm. 


\section{TABLE 5 ABOUT HERE}

Related to this, a number of similarities and differences can be observed in the perceived impact of codes on labour rights among the different types of firms in each of the countries. The use of the nation states as the locus for consumer activism is clearly problematic. It is often assumed that South Africa has good labour laws, sometimes even described as 'Rolls Royce' labour laws, whereas Lesotho and Swaziland have weaker labour regimes. As a 'least developed country', Lesotho's state bureaucracy is underdeveloped, and Swaziland's labour statutes have some labour repressive elements as Africa's last remaining absolute monarchy. Indeed, because of this, Swaziland was almost excluded from the benefits of the AGOA. Our findings showed that there were differences in wages between the companies in the three countries and that there were significant wage differentials in garment factories within the three countries. More surprisingly, the differences in wages were the biggest in South Africa and there were some workers in South Africa who were paid wages much lower than their counterparts in Lesotho (see Table 5 above). To be sure, government enforcement of minimum standards in all three cases seemed rather weak.

Also, codes inspectors tended to focus on standards (such as working hours, health and safety), not rights to freedom of association and collective bargaining rights. Trade unions were only engaged at a superficial level. Codes often only contain limited areas of adherence, with references to 'the need to adhere to/comply with local legislation.' As local legislation often sets low standards, such as (very) low minimum wages, or is weakly enforced, it is relatively easy to adhere to. In some cases this did not even take place. Our interviews with 
management also revealed that the conditions stated in the codes were not challenging them to take wide-ranging steps to improve conditions.

Fierce price competition in the industry, including increasingly tough demands on frequency of delivery, improved quality and delivery on time, put limitations on what could reasonably expected from codes. Both Swaziland and Lesotho initially attracted the industry by offering low wages and other incentives (tax holidays, reduced rates on water and electricity among others). Because of an absence of any particular strategy regarding sustaining the industry, the local industry is vulnerable in situations where changes in the global industry are frequent and the future decisions of major buyers not predictable. While government agencies like the Lesotho National Development Cooperation and the Swaziland Investment Promotions Agency are doing qualified work in lobbying and attracting companies to the countries (Interviews: Mabuza; Mohale, Tshukulu \& Jasina), lack of industrial policies (Interviews: Kathide \& Le Roux; Dlamini; Seleteng) leave worthwhile efforts like Lesotho's training scheme (ComMark, 2003; 2007) difficult to sustain. This begs the question as to what happens when the industry is no longer competitive (in the cases of South Africa and Swaziland) and major firms no longer source garments from the country, as seems to be the case in Lesotho (see Seidman, 2009).

During our latest visit to Lesotho and Swaziland there was evidence that government officials were disillusioned with the outcomes of their approach to the industry. In Lesotho there were attempts to reposition the country as a "sweat-free" manufacturing site, and in Swaziland consultants were engaged to work with firms to formulate longer-term strategies (Interviews: Nkambule, Matsoso, Mohapi). A focus on labour rights, however, was not on the agenda.

Our study points to a dilemma. Critics of codes, such as Seidman (2007), argue that the state should be responsible to regulate labour conditions. But what if the state is unable or 
unwilling to do so, as Burawoy (2010) points out? The alternative could be the strengthening of civil society, in particular trade unions as representatives of employees. This, as our study shows, is also not a straightforward matter. One approach could be for codes inspectors to shift their emphasis from standards to rights. Another is for global bodies, such as the ILO, to become more centrally involved. It is too soon to tell what the impact will be of the ILO's Better Work Programme in Lesotho (Interview: Kurths). Further research is needed into cases where solutions are found to such dilemmas.

Clearly national policies are not adequate, nor, for now, are such voluntary initiatives. Given the absence of a coherent global approach to the governance of trade the garment industry, codes of conduct will remain an inadequate response to the structural abuse of workers' rights, also in southern Africa. 


\section{Bibliography}

Barrientos, S, Dolan, C \& Tallontire, A, 2003. A gendered value chain approach to codes of conduct in African horticulture. World Development 3(9), 1511-1526.

Barrientos, S \& Smith, S, 2007. Do workers benefit from ethical trade? Assessing codes of labour practice in global production systems. Third World Quarterly 28(4), 713-729.

Bennett, M, 2006. Lesotho. In Jauch, H \& Traub-Merz, R (Eds.), The Future of the Textile and Clothing Industry in Southern Africa. Friedrich Ebert Stifftung, Bonn.

Bonacich, E \& Appelbaum, R, 2000. Behind the Label. University of California Press, Berkeley.

Burawoy, M, 2010. From Polanyi to Pollyanna: The false optimism of global labour studies. Global Labour Journal 1(2), 301-313.

ComMark, 2003. Report on the productivity audit and training needs analysis for the garment industry in Lesotho. ComMark Trust, Maseru.

ComMark, 2007. The current state of Lesotho's textile and apparel industry - economic situational analysis. ComMark Trust, Maseru.

De Haan, E \& Stichele, MV, 2007. Footloose investors: Investing in the garment industry in Africa. SOMO (Centre for Research on Multinational Corporations), Amsterdam.

Department for International Development (DfID), 2000. Making markets work better for the poor: A framework paper. DfID, London.

Fig, D (Ed.), 2007. Staking their Claims: Corporate Social and Environmental Responsibility in South Africa. University of KwaZulu-Natal Press, Scottsville. 
Gereffi, G, 1995. Global production systems and Third World development. In Stallings, B (Ed.), Global Change, Regional Response: The New International Context of Development. Cambridge University Press, New York.

Gereffi, G \& Memedovic, O, 2003. The global apparel value chain: What prospects for upgrading by developing countries? UNIDO, Vienna.

Gibbon, P, 2002. South Africa and the global commodity chain for clothing: Export performance and constraints. CDR Working Paper 12.7., Centre for Development Research, Copenhagen, Denmark.

I-Net Bridge, Clothing retailers consider outsourcing. 13 September 2010.

Jenkins, R, Pearson, R \& Seyfang, G, 2002. Corporate Responsibility and Labour Rights: Codes of Conduct in the Global Economy. Earthscan, London.

Jeppesen, S \& Barnes, J, 2011. Making industrial policy work in an era of globalisation: The case of South Africa and the textiles and clothing industry. In: Rugraff, E \& Hansen, MW (Eds.), Multinationals and Local Firms in Emerging Markets. Amsterdam University Press, Amsterdam.

Kaplinsky, R, 2005. Globalisation, Poverty and Inequality: Between a Rock and a Hard Place. Polity Press, Cambridge.

Kaplinsky, R \& Morris, M, 2008. Do the Asian drivers undermine export-oriented industrialization in SSA? World Development 36(2), 254-273.

Locke, R \& Romis, M, 2009. The promise and perils of private voluntary regulation: Labor standards and work organization in two Mexican garment factories. Politics \& Society 37(3), 319-351. 
Madonsela, WS, 2006. Swaziland. In Jauch, H \& Traub-Merz, R (Eds.), The Future of the Textile and Clothing Industry in Southern Africa. Friedrich Ebert Stifftung, Bonn.

Morris, M \& Reed, L, 2008. Review of the impact of the China restraint agreement on the clothing and textile industry in South Africa. University of Cape Town, Cape Town.

Ravioli, P, 2006. The Travels of a T-shirt in the Global Economy: An Economist Examines the Markets, Power and Politics of World Trade. John Wiley, New Jersey.

Seidman, GW, 2007. Beyond the Boycott: Labor Rights, Human Rights and Transnational Activism. Russell Sage Foundation, New York.

Seidman, GW, 2008. Transnational labour campaigns: Can the logic of the market be turned against itself? Development and Change 39(6), 991-1003.

Seidman, GW, 2009. Labouring under an illusion? Lesotho's 'sweat-free' label. Third World Quarterly 30(3), 581-598.

Silver, B, 2003. Forces of Labour: Workers' Movements and Globalization since 1870.

Cambridge University Press, Cambridge.

Southall, RJ, 1995. Imperialism or Solidarity: International Labour and South African Labour Trade Unions. UCT Press, Cape Town.

Vlok, E, 2006. South Africa. In Jauch, H \& Traub-Merz, R (Eds.), The Future of the Textile and Clothing Industry in Southern Africa. Friedrich Ebert Stiftung, Bonn. 
Table 1: Is there a code of conduct that applies to your workplace?

\begin{tabular}{|l|c|c|c|}
\hline & South Africa & Lesotho & Swaziland \\
\hline Yes & $14(46.7 \%)$ & $26(65 \%)$ & $29(58 \%)$ \\
\hline No & $7(23.3 \%)$ & $14(35 \%)$ & $8(16 \%)$ \\
\hline Don't know & $9(30 \%)$ & $0(0 \%)$ & $13(26 \%)$ \\
\hline
\end{tabular}

$\mathrm{N}=120$ 
Table 2: Is there a monitoring of wages and working conditions by government officials?

\begin{tabular}{|l|c|c|c|}
\hline & South Africa & Lesotho & Swaziland \\
\hline Yes & $7(23.3 \%)$ & $3(7.7 \%)$ & $6(12 \%)$ \\
\hline No & $20(66.7 \%)$ & $33(84.6 \%)$ & $42(84 \%)$ \\
\hline Don't know & $3(10 \%)$ & $3(7.7 \%)$ & $2(4 \%)$ \\
\hline
\end{tabular}

$\mathrm{N}=120$ 
Table 3: How often does a union visit your workplace?

\begin{tabular}{|l|c|c|c|}
\hline & $\begin{array}{c}\text { South } \\
\text { Africa }\end{array}$ & Lesotho & Swaziland \\
\hline Every week & $3(14.3 \%)$ & $23(69.7)$ & $7(21.9 \%)$ \\
\hline Only when there is a problem & $3(14.3 \%)$ & $1(3 \%)$ & $0(0 \%)$ \\
\hline $\begin{array}{l}\text { Union never comes, not } \\
\text { allowed in }\end{array}$ & $11(52.4 \%)$ & $3(9.1 \%)$ & $17(53.1 \%)$ \\
\hline Other & $4(19 \%)$ & $6(18.2 \%)$ & $8(25 \%)$ \\
\hline
\end{tabular}

$\mathrm{N}=86$ (Other responses included 'once a year,' 'once a month,' 'not often,' etc.) 
Table 4: Are you a member of a trade union?

\begin{tabular}{|l|c|c|c|}
\hline & South Africa & Lesotho & Swaziland \\
\hline Yes & $7(23.3 \%)$ & $10(25 \%)$ & $23(46 \%)$ \\
\hline No & $23(76.7 \%)$ & $30(75 \%)$ & $27(54 \%)$ \\
\hline
\end{tabular}

$\mathrm{N}=120$ 
Table 5: Average weekly wages of workers interviewed by firm, all values equivalent to the South African Rand

\begin{tabular}{l|c}
\hline Lesotho1 & 182.03 \\
Lesotho2 & 182.63 \\
Lesotho3 & 187.89 \\
Lesotho4 & 184.20 \\
Swaziland1 & 289.06 \\
Swaziland2 & 255.19 \\
Swaziland3 & 307.77 \\
Swaziland4 & 207.21 \\
Swaziland5 & 210.32 \\
South Africa1 & 167.50 \\
South Africa2 & 356.00 \\
South Africa3 & 271.67 \\
South Africa4 & 306.00 \\
\hline Total & 233.7408 \\
\hline
\end{tabular}


Appendix A: Size, ownership and location of the twelve firms interviewed

\begin{tabular}{|l|l|l|l|}
\hline & Size (Number of employees) & Ownership & Location \\
\hline Lesotho 1 & $450-500$ employees. & Taiwanese & Maseru \\
\hline Lesotho 2 & 4000 employees. & Taiwanese & Maseru \\
\hline Lesotho 3 & 1800 employees & South African & Maputsoe \\
\hline Lesotho 4 & 7000 employees & Taiwanese & Maseru \\
\hline Swazi 1 & $450-500$ employees & Taiwanese-Swazi & Manzini \\
\hline Swazi 2 & 1300 employees. & South African & Manzini \\
\hline Swazi 3 & $350-400$ employees & Taiwanese & Manzini \\
\hline Swazi 4 & 600 employees & Taiwanese & Nhalangano \\
\hline Swazi 5 & Unknown & Taiwanese & Manzini \\
\hline SA 1 & 150 employees. & Chinese & Ladysmith/Ezakheni \\
\hline SA 2 & 250 employees. & South African & Ladysmith \\
\hline SA 3 & 400 employees & South African & Ladysmith \\
\hline SA 4 & Unknown & Ladysmith \\
\hline
\end{tabular}




\section{Appendix B: Interviews with key respondents and firms in Lesotho, Swaziland and South Africa, May, September and October 2008, March 2011}

Barnes, Justin, CEO, B \& M Analysts, Durban, South Africa. Several interviews and email exchanges prior to, during and after the field trips.

Bennet, Mark, Textile and Apparel Value Chain Specialist, Southern African Trade Hub, Gaborone. Several interviews and email exchanges prior to, during and after the field trips.

Billy, Macaefe (Mr), General Secretary of Factory and Allied Workers' Union (FAWU) and Mr Stephen Likoti, Deputy General Secretary, FAWU, FAWU office, Maseru, Lesotho, 20.05.2008

Chen, Jennifer (Ms), President of Lesotho Textile Exporters Association (LTEA), Maseru, Lesotho, 16.10.2008

Dlamini, Phumelele (Mrs), Head of Industry Section, Department of Enterprise, Manzini, Swaziland, 10.09.2008

Fakudze, Alex (Mr) \& Mr Sipho Manana, President \& General Secretary of Swaziland Manufacturing \& Allied Workers Union (SMAWU), Manzini, Swaziland, 15.09.2008

Financial Controller, Taiwanese owned factory, Manzini, Swaziland, 19.09.2008

Gina, Mduduzi (Mr), General Secretary of Swaziland Processing, Retail and Allied Workers' Union (SPRAWU), and Mr Hlangani Simelane, Deputy General Secretary, SPRAWU, SPRAWU Office, Manzini, Swaziland, 23.05.2008

Khathide, Madoda (Mr), Executive Manager, Economic Development, Emnambithi/Ladysmith Municipality \& Mr Bertie Leroux, Manager, Economic Development, Ladysmith, South Africa, 20.10.2008

Kipling, Jack (Mr), President CLOTRADE (Clothing Trade Council of South Africa), Cape Town, South Africa, 13.10.2008

Kurths, Kristina (Ms), Programme Manager, Better Work Lesotho, Maseru, Lesotho, 24.03.2011

Mabuza, Sabelo (Mr), Director - Investment Facilitation and After Care, Swaziland Investment Promotion Agency (SIPA), Mbabane, Swaziland, 15.09.2008

Madlala, Sam (Ms), Inspection Officer, Department of Labour, Ladysmith, South Africa, 17.10.2008

Manager, South African owned factory, Ladysmith, South Africa, 20.10.2008

Manager, Taiwanese owned factory, Maseru, Lesotho, 15.10.2008

Managing Director, South African owned factory, Ladysmith, South Africa, 21.10.2008 
Managing Director, South African owned factory, Maputsoe, Lesotho, 16.10.2008

Managing Director, Swazi-Taiwan Joint Venture, Manzini, Swaziland, 17.09.2008

Managing Director, Taiwanese owned factory \& PA to MD, Maseru, Lesotho, 16.10.2008

Managing Director, Taiwanese owned factory, Nhlangano, Swaziland, 18.09.2008

Maraisane, Daniel (Mr), General Secretary of Lesotho Clothing and Allied Workers' Union (LECAWU), LECAWU office, Maseru, Lesotho, 20.05.2008

Matsoso, Mamohale (Mrs), Labour Commissioner, Labour Department, Maseru, Lesotho, 20.05.2008 and 25.03.2011

Mhlongo, Mndeni (Mr), Designated Agent, National Bargaining Council for the Clothing Manufacturing Industry, Labour Affairs Division, Ladysmith, South Africa, 20.10.2008

Mohale, Molupe (Mr), Project Manager, Mr Sello Justice Tshukulu, Manager, and Mrs. Mabeibi Jasina, Foreign Investment Promotion Officer, Lesotho National Development Corporation (LNDC), LNDC Office, Maseru, Lesotho, 21.05.2008

Mohapi, 'Matamatama, Planning and Research Officer, Lesotho National Development Corporation, Maseru, Lesotho, 24.03.2011

Mthembu, Israel, (Mr), Regional Coordinator, Southern African Clothing and Textile Workers' Union (SACTWU), Ladysmith, South Africa, 20.10.2008

Nkambule, Mandla (Mr), Director, Investment Facilitation and Aftercare, Swaziland Investment Promotion Authority, Nick Singer, Technoserve and Michelle Lehrer, European Director, Supply Chain Labour Practices, Mbabane, Swaziland, 23.03.2011

Nkhambule, Jinnoh (Mr), Commissioner of Labour \& Mrs Khabo Dlamini, Principal Labour Officer, Department of Labour, Mbabane, Swaziland, 18.09.2008

Owner \& Production Manager, Taiwanese owned factory, Ladysmith, South Africa, 20.10.2008

Production Manager, Chief Engineer, HR Manager, South African owned factory, Manzini, Swaziland, 16.09.2008

Regional Manager, Taiwanese owned factory, Maseru, Lesotho, 14.10.2008

Seleteng, Relebohile (Ms), Senior Industrial Development Officer, Ministry of Trade \& Industry, Cooperatives and Marketing, Maseru, Lesotho, 15.10.2008

Vlok, Etienne (Mr), Trade Policy Unit, SACTWU (South African Clothing and Textiles Workers' Union), Cape Town, South Africa, 13.10.2008 
Wenham, Kim (Ms), Property Manager, Ithala, Ezahkeni Industrial Estate \& Mr Leon

Steenkamp, Maintenance Manager, Itahala, Ezakheni and Madadeni Industrial Estates, South Africa, 17.10.2008 